\title{
15 Marketing
}

\subsection{Introduction}

Marketing is one of the most important aspects of nursery crop production. Marketing of any business is broken down by using the 4P's: Product, Price, Promotion and Placement.

Product: A nurseryman must let everyone know about the business and how your product is superior to the already available product in the trade. First, every business should have a plan to market the product. A marketing plan should cover the following questions:

What or Who is your market?

How will you identify your product to the market?

Price: In the first instance, the price should be fixed high enough to generate a profit for the business. In fixing price, the following factors should be taken into considerations:

- What are customers willing to pay?

- Are all costs covered; where do you break even?

- What does the competition charge?

- How much profit do you want to generate?

Promotion: This is the strategy that a person uses with the customer to encourage them to purchase the product. Promotion includes advertisement, public relations and personal contact.

Placement: When the product is ready for sale, has been priced and consumers know that it exists, how do they get? This is called placement of the product or getting the goods to the customers i.e., distribution. A nurseryman must rely upon distribution channels like wholesalers, retailers, distributors, brokers and cooperatives.

\subsection{Marketing Channels}

There are various markets for nursery crops including landscape contractors, garden centres, mass merchandisers, other growers, brokers, agricultural producers and home owners. Most nursery crops are sold at the wholesale level. The major wholesale market is the garden center. Brokering is a small but useful market channel for new growers with a limited product line, insufficient market contacts or poor marketing skills. Direct selling of product to the consumer is attractive because it maximizes the price per plant. Those engaging in direct farm marketing should have a building permit to ensure compliance with building codes, a business license or registration, liability insurance and signs that meet standards with respect to placement, size, location and type of sign used.

(cc)BY-NC-ND (C) 2014 Lakshman Chandra De, Promila Pathak, A.N. Rao, P.K. Rajeevan 
Mail order selling is another form of retailing that does not require face to face business with the client. Internet websites can bring the world market place to the door of even the smallest nursery business at a reasonable cost. Nursery management has attained a status of a commercial venture where retail nurseries sell planting materials to the growers and general public. It includes the following aspects:

- Capital investment in nursery development

- Process of distributed nursery production

- Knowing the government loan and subsidies available for nursery development

- Analysis of income, expenditure and profit in nursery management

- Understanding the role of horticultural nurseries in entrepreneurship development

\subsection{Capital Investments in the Nursery Development}

A large volume nursery requires a full time manager and considerable capital investment, while a small volume nursery requires a part time job and less capital investment. A plant nursery needs various capital components of expenditure like land, building, road, fencing, polyhouse, mother plant block, shade net, equipment, machinery, office stores, well/ tube well, motors, irrigation systems etc. The cost and expenditure components for non-recurring heads that are included under capital components are seed beds, nursery beds, potting mixtures and potting yards, polyhouse, mist chambers, polytunnels.

\subsection{Marketing of Plants from Nurseries}

Based on demand survey, the cost of various nursery plants are fixed depending upon the age of plants, height of plants, variety, propagation techniques used, production costs, maintenance costs etc. There should be adequate publicity and advertisement of availability of various grafts and seedlings in the nursery. This includes advertisements in the sales area, advance booking, information through gram sabhas, exhibition through stalls, advertising through newspaper and magazine, publicity in weekly bazaars, posters, appointing sale agents, information brochure, and printing catalogues.

\subsection{Government Regulations and Support Nursery}

The availability of quality planting materials is the main criteria for the success of horticulture industry. Nursery Registration Act is at present in force in the states of Punjab, Maharashtra, Himachal Pradesh, Uttar Pradesh, Uttarakhand, J\&K, Orissa and Tamil Nadu. A system of monitoring exists for horticulture nurseries in the 
states of Andhra Pradesh, Assam, Bihar, Goa, Haryana, Karnataka and Kerala while there is no horticulture nursery Act in the states of Arunachal Pradesh, Chhatisgarh, Jharkhand, M.P., Manipur, Meghalaya, Mizoram, Nagaland, Rajasthan, Sikkim, Tripura and West Bengal. It is essential to adopt quality standards for Horticulture Nurseries to facilitate, promote and monitor production and trade of quality planting materials of horticultural crops which are propagated vegetatively.

A nursery must set certain standards and these standards are categorized into three main groups, cost efficiency, quality and size. Cost efficiency includes the cost of production, profit and sales price. Quality standards include general plant health, hardness or softness of plant tissue, uniformity, labeling etc. Size standards include pot size for trees, shrubs, herbs and indoor plants; and plastic punnets for seedling vegetables and flowers etc.

\subsection{Support for Nurseries under National Horticulture Mission (NHM)}

The National Horticulture Mission has given important focus on production and distribution of good quality seeds and planting materials. Most of the States have a network of Central or State assisted nurseries for producing planting materials. Assistance for infrastructure in nurseries includes the following:

- Proper fencing.

- Mother stocks block maintenance under polycover to protect from adverse weather conditions.

- Raising rootstock seedlings under shade net house conditions.

- Propagation house, tropical polyhouse with ventilation having insect proof netting on sides and fogging and sprinkler irrigation systems.

- Hardening / maintenance in insect proof net house with light screening properties and sprinkler irrigation systems.

- Pump house to provide sufficient irrigation to the plants and water storage tank to meet at least two days requirement

Under the revised guidelines of NHM, assistance can be provided for setting up a nursery of 1 ha costs Rs. 6.25 lakhs and maximum area of 4ha with a total cost of Rs. 25 lakhs. The nurseries in the public sector are given 100\% assistance and for those under the private sector $50 \%$ assistance is provided as credit linked back and subsidies. Nurseries that are 1 ha are classified as small nurseries and beyond that are classified as large nurseries. Each nursery has to produce a minimum 50,000 plants per ha per year of the mandated perennial fruit plant /tree spices/ plantation crop through vegetative propagation. The nurseries have to supply quality planting materials. In order to ensure the supply of quality planting material, the planting material must be purchased from the nurseries which are accredited by the National Horticulture Board, SAU's and ICAR institutes. 


\subsection{Nursery Expenditure, Income and Profit Analysis}

The nursery enterprise is an important source of employment and income generation and depends upon proper planning of work, man power, raw material and proper financial appraisal. Entrepreneurs may use business analysis as a tool for important decisions such as business expansions, financing, marketing strategies, operations planning and product selection. With proper implementations, this information may increase nursery business profitability, control costs, reduce the risk of business failure, boost employee productivity and job satisfaction, enhance physical efficiency and increase management professionalism. Financial analysis assists in identifying some common problems in wholesale plant nurseries such as low output, slow crop growth or poor pricing, excessive costs, waste or overuse, poor cash flow, over-capitalization or under-capitalization and imbalanced debt structure.

\subsection{Expenditure Estimate in Nursery}

The estimate of expenditure in a nursery consists of two major components fixed costs and variable costs. Fixed cost components include one-time capital investment include fencing, workshed, mother plant block, irrigation with pipe line, office-cumstore, shade net house, mist chamber, polytunnel, seedbeds, nursery beds, internal roads, pathways, polling yard, water storage. Variable cost is the amount used by a business unit to fulfill its daily requirements. Variable cost components include labourer, raw materials, like media, polybags, fertilizers, manures, pesticides and consumable items like labels, stationary, electricity and telephone.

\subsection{Nursery Income}

A nursery enterprise can have various sources of income such as the sale of saplings, grafts, vegetable seedlings, potted plants, bagged plants and ball seedlings, planting materials like seeds, bulbs and corms. They can sell other raw material and equipment like pots, bags, pruning and grafting implements etc. Other sources of income can be obtained from realization of commission, consultancy fee, subsidy, donation and minor sale of weed grass, fuel wood etc, and from the nursery.

\subsection{Maintenance of Records for Sale and Income}

The nursery should keep a record of mother plants illustrating both rootstock and scion trees, production of grafts and seedlings and sale of plants. Book keeping is another important function of financial accounting and it maintains proper records 
with complete details of business transactions. Business transactions are classified into several major activities or groups, e.g., sales, purchases, assets etc. Separate books are maintained for recording transactions. Details of transactions are recorded into respective headings.

Purchase books are maintained to record all transactions pertaining to purchases on credit or cash. Sales books are maintained to record all transactions related to credit or cash sales. Ledgers are maintained to record all accounts involved in the transactions.

A Cash book is maintained in a subsidiary book of the ledger for recording the account of cash. A Bank book is a subsidiary book of the ledger where the account of the bank is maintained. The Stock register is a register where the movement of stock is maintained.

\subsection{Profit Analysis and Financial Ratios (De, 2013)}

To make a nursery business economically viable and profitable, various financial ratios are taken into consideration and these ratios help the lenders to analyse the viability and profitability of the nursery enterprise. These financial ratios include return on investment covering both borrowed capital and owned capital, Debt Service Coverage Ratio (DSCR), Internal Ratio of Return (IRR), Break Even Point and Debt Equity Ratio.

$$
\mathrm{DSCR}=\frac{\text { Net profit }+ \text { Interest }+ \text { Tax }}{\text { Interest }+ \text { Principal loan }}
$$

A project remains viable if the minimum value of DSCR is 1.7.

IRR (Internal Return Rate) is the interest rate at which the net present value of costs of the investment equal the net present value of the benefits of the investments. IRR are used to evaluate the desirability of investments or projects.

Break Even Point (BEP): This is the level of activity where the total contribution is equal to the total fixed cost: Contribution $=$ Sales - Variable Cost

The BEP indicates the risk involved in a project.

Debt-Equity Ratio: This indicates the extent to which the funds of the promoter are leveraged to procure loans.

$$
\text { DER }=\frac{\text { Total long term debt }}{\text { Total promoters fund }}
$$

A higher debt enquiry ratio indicates more risk due to a higher fixed cost of interest. 


\subsection{Entrepreneurship Development through Nursery}

Nursery enterprise creates sizeable employment opportunities for the rural masses and the areas are production of seeds, seedlings, grafts, potted plants, ball plants, plants for aesthetic purposes in landscaping or management program on rental basis; sale of plants to retail nurseries; starting plant libraries; providing vegetable seedlings, ornamental plants and planting materials, medicinal and aromatic plants and tissue culture plants; landscape gardening and consultancy. A nursery entrepreneur undertakes a nursery business or an enterprise.

The qualities required for a nursery entrepreneur are as follows:

- Calculated risk takers

- Perceive opportunities very quick, synthesize the available information and analyze emerging pattern that escape the attention of others

- Desire to hit new goals

- Convert adversities into opportunities

- Seek out experts for assistance

- Take immediate feedback on performance and record prompt and accurate data

- Achievement driven person

- A successful entrepreneur plans while keeping an open mind to achieve goals in pre-scheduled time frame.

- A successful entrepreneur influences others and motivates them to think and act in his way.

\subsubsection{Role of Nursery Entrepreneurship}

A nursery enterprise aids in providing plants and planting material and other processes that indirectly help in the national economy. It also assists in gaining a more balanced financial development as the business flourishes both in urban and rural sector. It aids in empowering people by providing increased community participation. Another aspect of nursery enterprise is to contribute national economy by providing employment opportunities for the skilled and unskilled workers.

\subsubsection{Risk Analysis in Nursery Enterprise}

A nursery enterprise can be carried out successfully provided the raw material, labour, capital requirement, planning of expenditure and income and knowledge of market are carefully taken into consideration.

A number of factors that can lead to losses in a nursery enterprise and the factors are underutilization of capacity, untimely availability and sale of plants, production not as per demand, increasing competition poor recovery of credit sales, increasing cost of labour and raw material and poor technical knowledge. 


\subsubsection{Profitability in a Nursery Enterprise}

The profitability of a nursery enterprise depends upon assumptions of demand of plants and availability of various production inputs like raw material and labour.

Points to be considered to bringing nursery enterprise into a profitable venture

- Production of plants in a nursery in a commercial venture.

- Balancing the technical aspects and practical feasibility of production and sale of plants in a nursery

- Proper planning and execution of operations

- Maintenance and critical analysis of records of expenditure and income at regular intervals

- Monitoring of daily activities in nursery

- A proper coordination among production of plants, rearing of plants and sale of plants

- Increasing sales through aggressive marketing, publicity and advertisement in newspaper, magazines and other mass media.

\subsection{Export Market Views of Orchids}

- Southeast Asian countries such as Thailand, Singapore, and Malaysia are the major suppliers of tropical orchids to the world. Japan is considered one of leading orchid-importing countries, consuming $40 \%$ of the world supply. The European countries also consume $40 \%$ of the world supply while Australia, Hongkong, and the United States take up the remaining 20\%. Recognizing the immense potential of floriculture export, governments in the Asia-Pacific countries continue to support research and development by providing sophisticated laboratory testing and control apparatus to help growers improve quality and varieties. Distribution and transportation facilities are constantly upgraded and promotion activities conducted to nurture appreciation for plants and flowers.

- Dendrobium and Vanda are the most preferred orchids while the rose had the highest demand among ornamental plants. The price of flowers fluctuates widely depending on the occasion or season. Various factors affect pricing include supply and demand situation, cut-flower quality, and grading of cut orchids. In grading the cut orchids, size, color, freshness, and texture are considered.

- Proximity to export markets such as Japan and Taiwan is considered an advantage to orchid exporters. The bulk of the products are sold to commercial buyers and flower retailers.

- The creation of the Cut-flower Development Plan, and the enactment of the High Value Crop Law can enhance growth of the cut-flower industry.

- The serious problems that have been identified for growers, breeders, retailers, and traders are the lack of quality planting materials, improved production tech- 
nologies, inadequate capital investment, proper diagnosis and control of plant pests and diseases.

- To minimize problems that hinder the growth of the cut-flower industry, researchers recommended collaborative efforts among growers, breeders, traders, and retailers with assistance from the different government agencies, private sector, academia, financial institutions, and the media. There is also an urgent need to form cut-flower cooperatives, associations, and federations. The creation of allied services could be beneficial to the orchid industry in terms of having greater access to opportunities and addressing requirements of the cutflower growers. The cut-flower association's approach would be to provide technical and marketing assistance to grower members and would-be growers.

\subsection{Development of International Orchid Market}

The production of pot orchids and cut orchid flowers has increased rapidly since the early-1990s. More first-time orchid growers are becoming involved in producing orchids than ever before. Orchid production is turning into a true international business.

Since the signing of the CITES in the late 1970s, orchid trade across international boundaries has been regulated by this international treaty. Although CITES was designed to protect the threatened and endangered species of plants and animals, it plays a vital role on growers and traders who export and/ or import orchids. Through the efforts of the American Orchid Society and countries having large orchid-exporting businesses, CITES has slowly relaxed the control of trading on a limited number of commercially-important orchid genera.

During the $8^{\text {th }}$ Asia-Pacific Orchid Conference, held in March 2004 in Tianan, Taiwan, Mr. Andy Matsui first proposed the idea of forming a worldwide orchid producers' organization. With the help of the organizers of the Taiwan International Orchid Show (TIOS) and through the coordination of Dr. Yin-Tung Wang, Professor of Horticulture at Texas A\&M University, an organizational meeting was held in March at the 2006 TIOS. All of the attendees of this preparatory meeting expressed high interest in forming an international organization to represent the orchid growers. A second meeting was held during March: the 2007 TIOS. Mr. Andy Matsui, Dr. David Beck (a cut-flower cymbidium grower in New Zealand) and Dr. Yin-Tung Wang presided at this meeting. Over 70 representatives from several countries around the world in attendance elected Mr. Matsui the first President of the International Commercial Orchid Growers Organization (ICOGO). Dr. Yin-Tung Wang was elected the Executive Secretary, and Mr. Matsui donated $\$ 50,000$ to get the organization off the ground and to start functioning. Two orchid growers, Yupin Biotechnology and Chian Huei Flowers in Taiwan, pledged to donate to help with ICOGO. 


\section{The Objectives of ICOGO}

- Develop business models from the experience of successful growers and regions.

- Increase orchid trade around the world through more extensive marketing efforts.

- Enhance the availability of orchid varieties to benefit all parties in the industry.

- Disseminate information related to orchid production and orchid trade.

- Cooperate and support applied research and conservation that help the advancement of commercial orchid production with local, regional, national and international research agencies and institutions.

- Provide the necessary trade information among the members to enhance orchid trade and cooperation.

\section{The Functions of ICOGO}

- To develop a system to help and protect the exclusive orchid varieties and the exchange of breeding materials among orchid breeders, propagators, and producers worldwide.

- To assemble up to date orchid information and assist in developing new techniques for producing orchids more profitably.

- To promote the eradication and control of insect pests and diseases and mutations for producing quality plants.

- To participate in regulatory activities, i.e., CITES, government regulations, etc. to ease on international orchid trade.

- $\quad$ To provide the necessary trade information among members to enhance orchid trade and cooperation.

- To conduct trade shows and publish newsletters to enhance communication among the members.

\section{Geographical Regions}

- Region I: Europe

- Region II: The Americas

- Region III: North Asia

- Region IV: South Asia, Oceania, Australia, New Zealand

- Region: V: Africa, Middle Asia

\section{Membership Classes}

- Full Members

- Commercial orchid growers, production area $\geq 1,000 \mathrm{~m}^{2}$.

- Have voting rights.

- Associate Members

- Allied suppliers, equipment \& greenhouse manufacturers, orchid-related businesses, employees of Full Members, educators, researchers, members of government and regulatory agencies, orchid organizations, etc.

- Have no voting rights. 
ICOGO's headquarters is currently located in the United States and it has been registered with the State of California. The orchid trade has just passed its infancy stage and there is a tremendous avenue for growth in the years to come.

\subsection{Domestic Orchid Market}

In India, it took a century for Sikkim and the northeastern region to realize the potential of Cymbidium, together with five other orchids - Dendrobium, Vanda, Cattleya, Phalaenopsis and Oncidium - as revenue earners. Flowers became a commercial prospect for us 10 years ago. It is a late start but is turning out to be a promising sector.

Sikkim annually produces Rs 20 million worth of orchids on an average. A cut stalk (spike) costs between Rs.20 and Rs.150 depending on the quality. The state government has introduced a special package in 18 clusters under which 50 flori-farmers have been given 500 orchid plantings (saplings) each with necessary support for cultivation, training and marketing. The state has to overcome several challenges to send the produce out to the national market. The first hurdle is transportation to the nearest marketplace. An effective cold chain is another area of concern.

The state requires refrigerated vans to the cold storages, and then the flowers are flown out. Orchids and other horticultural products are marketed by SIMFED - the government's national sales network. Veteran flower trader Andy Warren, managing director of the New Zealand-based company Bloomz, proposed that Sikkim and the northeastern states - (the country's traditional orchid hothouses) should concentrate on the domestic market and explore its "optimal capacity" for high returns instead of eyeing bigger export shares globally. This region lacks post-harvest facilities such as good packaging houses and cold storages. During hot summer logistics to move the harvested products are inadequate. Flowers like orchids wilt. The region needs to look at expanding markets in New Delhi, Mumbai, Bangalore and Chennai to fetch good prices. The critical thing is to ensure top quality in the market every day. This observation was made by Warren, who has been trading flowers with India for the last 20 years, to IANS at the Sikkim International Flower Show 2013. According to his concern, going to the international market is a "whole new ball game" with its own stringent set of standards.

\section{Producers}

- Open to certification

- Require support and extension service

\section{Government strategies}

- Clear Good Agricultural Practices (GAP) framework at national level

- Strengthen Standard knowledge \& dissemination

- Promote production of high quality orchids: GAP farm 


\section{Which information is still needed?}

- Do producers benefit from certification? (i.e. welfare, access to export markets)

- Information on environmental and social impacts

- Views of other stakeholders in importing countries i.e. buyers in EU 